\title{
Municipal Solid Waste Generation and Characterization in Ensenada, Mexico
}

\author{
Q. Aguilar-Virgen ${ }^{*}, 1,2$, C. Armijo-de Vega ${ }^{1}$, P.A. Taboada-González ${ }^{1,2}$ and S. Ojeda-Benítez ${ }^{3}$
}

${ }^{I}$ Faculty of Engineering in Ensenada, Autonomous University of Baja California, Tijuana-Ensenada Highway, $103 \mathrm{~km}$ South of Tijuana, Ensenada, Baja California, 22870, Mexico

${ }^{2}$ Doctoral Degree Students of the Program Master's Degree and Doctoral Degree in Sciences and Engineering of the Autonomous University of Baja California, Mexico

${ }^{3}$ Institute of Engineering, Autonomous University of Baja California, Benito Juárez Blvd. and De la Norma St., Mexicali, Baja California, 21280, Mexico

\begin{abstract}
A comprehensive study of the generation and characterization of municipal solid waste is essential to the longterm efficient and economical planning for solid waste management. The aim of this study was to quantify and analyze the solid waste generated in the city of Ensenada, Mexico, and to use this data in a project that will generate energy through methane gas production. Ensenada's per capita waste generation is approximately $0.87 \pm 0.07 \mathrm{~kg}$ per person per day within a $98 \%$ confidence interval. Ensenada's solid waste composition consists of food scraps at 34.28\%, paper and cardboard $22.49 \%$, plastic $12.53 \%$, disposable diapers $7.14 \%$, and textiles $6.58 \%$. Of the total waste generated, $86.36 \%$ has potential for reuse, whereas $13.65 \%$ has no further identifiable use and must be landfilled. Of the usable percentage, $48.34 \%$ can be recycled and $51.66 \%$ can be used to generate energy, obtaining financial and environmental benefits.
\end{abstract}

Keywords: Municipal solid waste, waste composition, recovery.

\section{INTRODUCTION}

In many developing countries, the operation and management of municipal solid waste (MSW) collection services are fairly rudimentary. This is reflected in the lack of information about the quantities and types of MSW collected, the amounts recovered, recycled and/or reused and the sitting of MSW disposal sites [1,2].

Data on the generation and composition of solid waste is key in order to plan for the long term management of solid waste in an efficient and economical manner. Such management includes the selection and operation of equipment for the treatment and handling of waste, and the types of disposal facilities that will allow for energy generation and resource recovery [3-7].

It is well-known that MSW can be used to generate electricity. Research published since the 1970's has reported the use of the biodegradable component in MSW to generate biogas, which can also be used to generate electricity and has positive environmental implications, such as the reduction of greenhouse gas emissions from sanitary landfills and the replacement of highly polluting energy sources (oil, coal and natural gas) [8-19].

The generation and composition of household waste are not homogeneous. They vary according to changes in consumer patterns and economic growth rates and depend upon standard of living, season of the year, day of the week,

*Address correspondence to this author at the Faculty of Engineering in Ensenada, Autonomous University of Baja California, Tijuana-Ensenada Highway, $103 \mathrm{~km}$ South of Tijuana, Ensenada, Baja California, 22870, Mexico; Tel/Fax: 52(646) 174-4333, E-mail: qaguilarv@gmail.com population habits and the geographical site of human settlement [3, 20,21]. By the same token, the generation and composition of waste have been influenced by economic recessions, the impact of legislation and the economic instruments to increase or decrease their value, e.g., reuse and recycling [3].

In order to determine the generation and composition of MSW, different methodologies can be used for sampling. Sampling can be through door-to-door waste collection or directly from waste collection trucks. As to sample size, Tchobanoglous et al. [4] explains that 90-kilogram samples do not change significantly out of the ones taken in sampling of up to 770 kilograms obtained from the same load of waste. Other research carried out shows that samples taken for analysis can be between 90 and $180 \mathrm{~kg}[3,5,22]$. Chung \& Poon [23] reports that sample size fluctuates between 20 to $30 \mathrm{~kg}$, $90 \mathrm{~kg}$, 100 to $200 \mathrm{~kg}$, and up to samples of around 5 to 7 tons of solid waste a week.

In Mexico, very few studies report the quantification and characterization of MSW; these were undertaken only in Morelia, Guadalajara, Chihuahua and Mexicali. In these studies, the data was collected through door-to-door and the sample size was variable since it was determined by the number of housing structures containing from 160 to 300 housing units. At the same time, some research was carried out by socioeconomic stratification (low, median and high) and others as a single unit without socioeconomic stratification [24-29].

\section{MUNICIPAL WASTE MANAGEMENT IN ENSENADA, B.C., MEXICO}

The MSW generated in Ensenada is disposed of in the sanitary landfill (SL) of the city. The MSW is transported to 
the SL mainly by municipality-run collection vehicles, and private operators. The special management waste and the industrial non-hazardous waste are not collected by municipality-run collection trucks, but by: 1) wastegenerating companies and 2) private waste collection companies, which also dispose of these wastes in the landfill. The city of Ensenada provides waste collection services in the towns of El Sauzal and Rodolfo Sánchez T. (Maneadero) and these wastes are disposed of in the SL of Ensenada.

The frequency of waste collection provided by the local government of Ensenada varies depending on the area: once/week for most waste collection routes $(1 / 7)$ and daily for downtown (7/7). The frequency of collection services provided by private operators varies depending on the client's needs.

The city of Ensenada has one waste transfer station which is privately operated. Currently, the operator and local authorities are studying a new approach for the collection vehicles owned and operated by the municipality to unload the wastes in the transfer station and, ultimately be transported to the SL by the private operator.

\section{MATERIALS AND METHODOLOGY}

The study was carried out in the city of Ensenada, municipal seat of the municipality of Ensenada in the state of Baja California, located in the northwest of Mexico. The municipality of Ensenada has a land area of 52,510.712 square kilometers and represents $74.84 \%$ of the total area of the state and $2.6 \%$ of the total area of Mexico, making it the largest municipality in the country.

\section{Characterization Study}

The waste characterization study was carried out during one week in February of 2009 at the ECO-TERRA Transfer Station in the city of Ensenada. The wastes deposited at the transfer station were initially characterized by socioeconomic stratification (low, median and high). To choose the waste collection trucks, several truck drivers were asked from which route (residential area) the waste was being collected until getting the first truck for every socioeconomic status a day. In order to choose the residential areas for every socioeconomic status, the Basic Geostatistical Area (AGEB) was taken as a reference, which was the stratification used by the National Institute of Statistics, Geography, and Data Processing (INEGI) in the population and housing census carried out in 2000. The criteria to establish the status of the residential areas were based on minimum wage, roofing and wall materials, and available public services, such as sewage infrastructure, running water and electricity.

The AGEBs corresponding to a low socioeconomic status were those where inhabitants' income was from less than and up to twice the minimum wage, most of the households' walls and roofs were light, natural and precarious, and limited access to sewage infrastructure, running water and electricity. The AGEBs where inhabitants' income was twice and up to five times the minimum wage were included in the median socioeconomic status, where most of the housing materials were concrete floor, brick, block, and cement and most of the households had access to sewage infrastructure, running water and electricity. The AGEBs where inhabitants' income was more than five times the minimum wage were included in the high socioeconomic status and the construction materials used in these households were high quality concrete, brick, block and cement and unlimited access to public services. The SCINCE software [30] of the INEGI was used to identify the AGEBs.

Once the waste collection trucks were chosen, approximately $100 \mathrm{~kg}$ of household waste load/socioeconomic status/ day were sampled. This figure is higher than that proposed in the Mexican Standard NMX-AA-0151985 (Quartering Method) [31], yet consistent with other research $[4,5,22,23]$. These samples were classified, weighed and registered.

The household waste was classified into different types according to the possibility of recovering the corresponding materials and placed into individual plastic containers. Two electronic weighing scales were used to weigh every single load: a 50-kg Torrey EQB_50/100 with a 10 -g least count and a $500-\mathrm{kg}$ Torrey L-EQM 500/1000 with a 100 -g least count. To quantify by-products, an index card based on the Mexican Standard NMX-AA-022-1985 (By-Product Selection and Quantification) [32] was used.

For composition analysis, the household waste was separated into three broad categories: 1) waste with potential for energy recovery, 2) recyclable waste, and 3) nonrecyclable waste. In the first category, food residuals, textiles, yard trimmings and other organic wastes (wood and leather) were gathered; in the second category, paper, cardboard, plastic, glass, tin cans and metals (aluminum, ferrous and non-ferrous metals) were gathered; and in the third one (non-recyclable), disposable diapers, inert waste (expanded polystyrene, construction materials, crockery and ceramics), other non-organics (electronic waste and batteries) and miscellaneous (fine waste, tetra pak packages, others) were gathered as well.

\section{Determination of the Generation of MSW}

In order to obtain a higher accuracy in the generation rates, daily data on the waste load weights collected by the trucks of the municipality were used. The data used in the study were collected in 12 whole weeks corresponding to the first quarter of 2009 (i.e., the 7 days of the week). Such information was provided by the Department of Municipal Public Works, which belongs to the Secretariat of Urban Management of the municipality of Ensenada. The entire population of 284,530 people from Ensenada, El Sauzal and Rodolfo Sánchez T. "Maneadero" was considered in order to obtain a per capita estimate, according to the INEGI's data, 2005. The MINITAB ${ }^{\circledR} 14.1$ program was employed within a $98 \%$ confidence interval, which was based on 12-week samples using the student's t-statistic.

\section{RESULTS}

The results the composition and quantification analysis of municipal solid waste in the city of Ensenada are shown in the next sections. As to the composition, 15 samples were taken of approximately $100 \mathrm{~kg}$ with the entire weight of $1,379.13 \mathrm{~kg}$ of the sample analyzed. As to the generation, we counted on data on daily waste load weights gathered in the first quarter of 2009. 


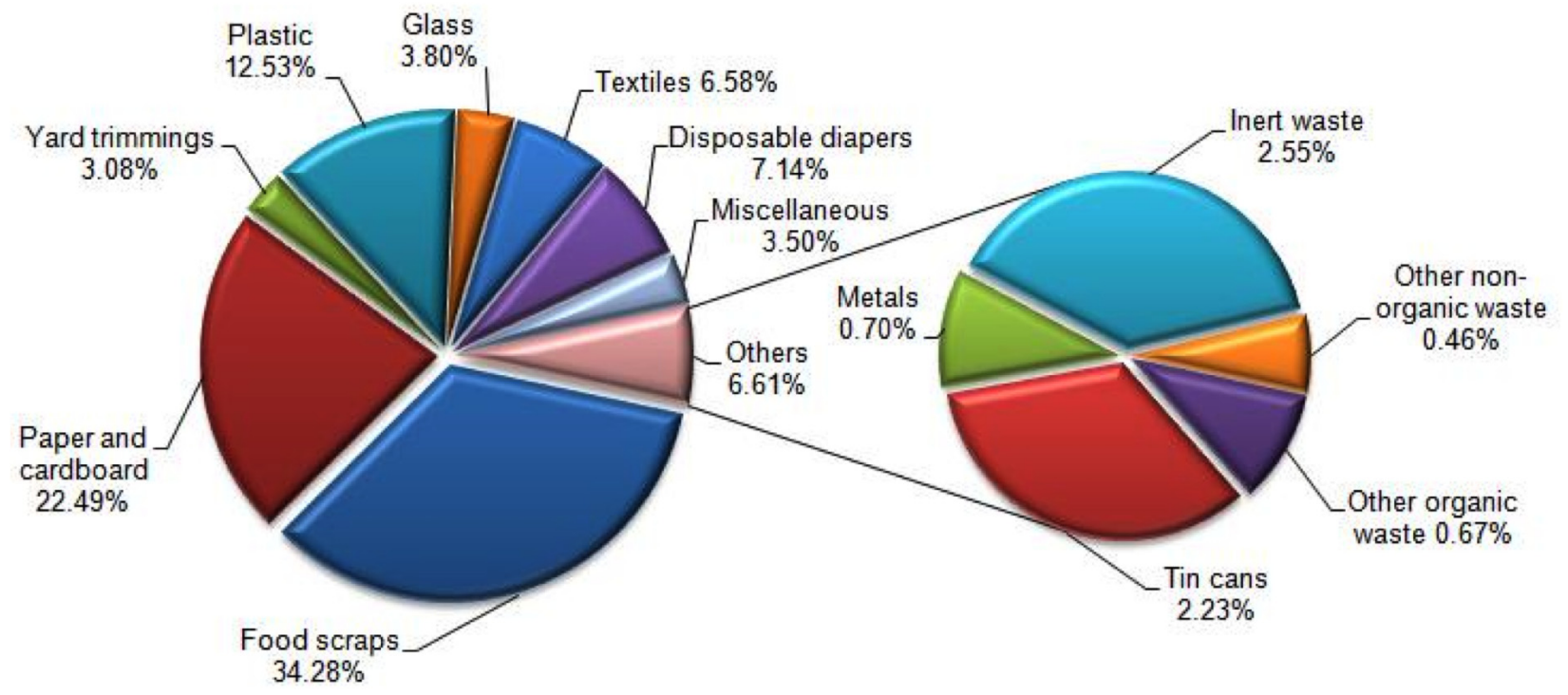

Fig. (1). Composition of MSW in Ensenada.

\section{Composition of Municipal Solid Waste}

A total waste load of $1,379.13 \mathrm{~kg}$ was weighed, out of which $439.02 \mathrm{~kg}$ belonged to the low socioeconomic status, $452.26 \mathrm{~kg}$ to the median status, and $487.85 \mathrm{~kg}$ to the high status. (Fig. 1) provides details regarding the composition of household waste (HW) generated by the combined three socioeconomic statuses in Ensenada over the entire study period. From these results, certain waste categories stand out: food residual accounts for $34.28 \%$, followed by paper and cardboard at $22.49 \%$, plastic at $12.53 \%$, disposable diapers at $7.14 \%$, and textiles at $6.58 \%$.

Of the total waste stream that is sent to the SL, $86.36 \%$ could be reused and just $13.65 \%$ has no use and must be discarded. Of the useful percentage, $48.34 \%$ is potentially recyclable with financial and environmental benefits, and $51.66 \%$ of the waste stream could be reused to generate energy. However, the waste at the SL is not being segregated for later reused. Therefore, the material disposed of is ultimately wasted.

Table 1 provides details regarding the composition of the HW generated by the socioeconomic statuses and, their percentages with respect to the total of categories.

As shown in the chart, the high socioeconomic status discards a higher amount of waste with potential for energy recovery at $46.53 \%$. As to food scraps, this status generates $39.29 \%$ in contrast to the low status, which generates only $30.59 \%$. Another category that stands out is textiles, which is the least generated by the high socioeconomic status at $3.22 \%$, as opposed to what it might be thought given their purchasing power and the ever-changing fashion trends.

As to recyclable waste, the high socioeconomic status has the most waste disposal at $43.73 \%$. The category "paper and cardboard" has the highest percentage in the three statuses, of which the low and high ones rank first and second, respectively. The category "plastics" ranks second at 13.01\% in the low socioeconomic status.
As to non-recyclable waste, $10.55 \%$ of disposable diapers are generated by the median socioeconomic status, followed by the low status at $6.96 \%$ and the high status at $4.14 \%$. As to the category "miscellaneous", the low status generates $5.74 \%$, containing organic and non-organic elements. As to the category "other non-organics", a greater amount was found in the low socioeconomic status at $0.67 \%$; this might be due to second-hand purchases of electronics, as well as disposable battery acquisitions, compared to the high status, which reports only $0.20 \%$.

\section{Determination of the Generation of MSW}

To determine the per capita generation, we counted on data provided by the municipality on daily weights of waste loads collected by the municipality-owned collection vehicles over the first quarter of 2009. Only weeks that had daily data were considered (i.e., whole weeks, Monday through Sunday) except the first and second weeks of 2009.

The average weekly generation of waste was $1,727.588 \pm$ 142.815 tons giving a per capita generation of $0.87 \pm 0.07 \mathrm{~kg}$ per person per day (see equations 1 and 2), where $\mathrm{pcg}_{\mathrm{m}}$ is the mean and $\mathrm{pcg}_{1}$ is the tolerance limit. (Fig. 2) provides details regarding the distribution of MSW collection by the municipality of Ensenada.

$$
\begin{aligned}
& p c g_{m}=\left[\frac{\left(\frac{1727,583 \mathrm{~kg}}{1 \text { week }}\right)\left(\frac{1 \text { week }}{7 \text { days }}\right)}{284530 \text { persons }}\right]=0.87 \frac{\mathrm{kg}}{\text { day } \times \text { person }} \\
& p_{c g_{l}}=\left[\frac{\left(\frac{142815 \mathrm{~kg}}{1 \text { week }}\right)\left(\frac{1 \text { week }}{7 \text { days }}\right)}{284530 \text { persons }}\right]=0.07 \frac{\mathrm{kg}}{\text { day } \times \text { person }}
\end{aligned}
$$


Table 1. Composition of the MSW by Socioeconomic Status

\begin{tabular}{|c|c|c|c|c|c|c|}
\hline \multirow{2}{*}{ Type of Waste } & \multicolumn{2}{|c|}{ LOW } & \multicolumn{2}{|c|}{ MEDIAN } & \multicolumn{2}{|c|}{ HIGH } \\
\hline & KG & $\%$ & KG & $\%$ & KG & $\%$ \\
\hline \multicolumn{7}{|l|}{ Energy recovery } \\
\hline Food scraps & 134.28 & $30.59 \%$ & 146.88 & $32.48 \%$ & 191.69 & $39.29 \%$ \\
\hline Textiles & 41.74 & $9.51 \%$ & 33.26 & $7.35 \%$ & 15.73 & $3.22 \%$ \\
\hline Yard trimmings & 6.05 & $1.38 \%$ & 18.92 & $4.18 \%$ & 17.54 & $3.60 \%$ \\
\hline Total & 187.26 & $42.65 \%$ & 201.11 & $44.47 \%$ & 227.00 & $46.53 \%$ \\
\hline \multicolumn{7}{|l|}{ Recyclable } \\
\hline Paper and cardboard & 104.35 & $23.77 \%$ & 90.17 & $19.94 \%$ & 115.66 & $23.71 \%$ \\
\hline Plastics & 57.13 & $13.01 \%$ & 56.12 & $12.41 \%$ & 59.47 & $12.19 \%$ \\
\hline Total & 182.49 & $41.57 \%$ & 179.94 & $39.79 \%$ & 213.34 & $43.73 \%$ \\
\hline \multicolumn{7}{|l|}{ Non-recyclable } \\
\hline Disposable diapers & 30.57 & $6.96 \%$ & 47.70 & $10.55 \%$ & 20.19 & $4.14 \%$ \\
\hline Inert waste & 10.52 & $2.40 \%$ & 9.62 & $2.13 \%$ & 14.92 & $3.06 \%$ \\
\hline Other non-organics & 2.96 & $0.67 \%$ & 2.33 & $0.52 \%$ & 1.00 & $0.20 \%$ \\
\hline Miscellaneous & 25.22 & $5.74 \%$ & 11.56 & $2.56 \%$ & 11.40 & $2.34 \%$ \\
\hline Total & 69.27 & $15.78 \%$ & 71.21 & $15.75 \%$ & 47.51 & $9.74 \%$ \\
\hline
\end{tabular}

\section{DISCUSSION}

\section{Composition of MSW}

Of the total amount of waste generated, $86.36 \%$ has the potential to be reused and just $13.65 \%$ must be discarded in the SL. In turn, out of the useful percentage, $41.75 \%$ could be recycled and $44.61 \%$ could be used to generate energy, thereby obtaining a host of financial and environmental returns. However, a study carried out by Ojeda et al. [33] in Mexicali shows that the potential for waste recycling in this city is $33.12 \%$ and the waste with potential for energy recovery represents $43.83 \%$. The reduction of potentially recyclable materials may be due to the fact that Mexicali disposes of less paper and cardboard, tin cans, and glass since it counts on more recycling companies, as opposed to the current situation in Ensenada, where there are no recycling businesses at all. The closest activities related to recycling are the drop off centers provided by companies or institutions.

In contrast to this study, another study carried out by the Secretariat of Social Development (SEDESOL) [34] in Ensenada shows that only $54.93 \%$ could be recycled (a percentage higher than those found) and $30.96 \%$ could be used to generate energy. Another study, carried out by the Secretariat of the Environment and Natural Resources

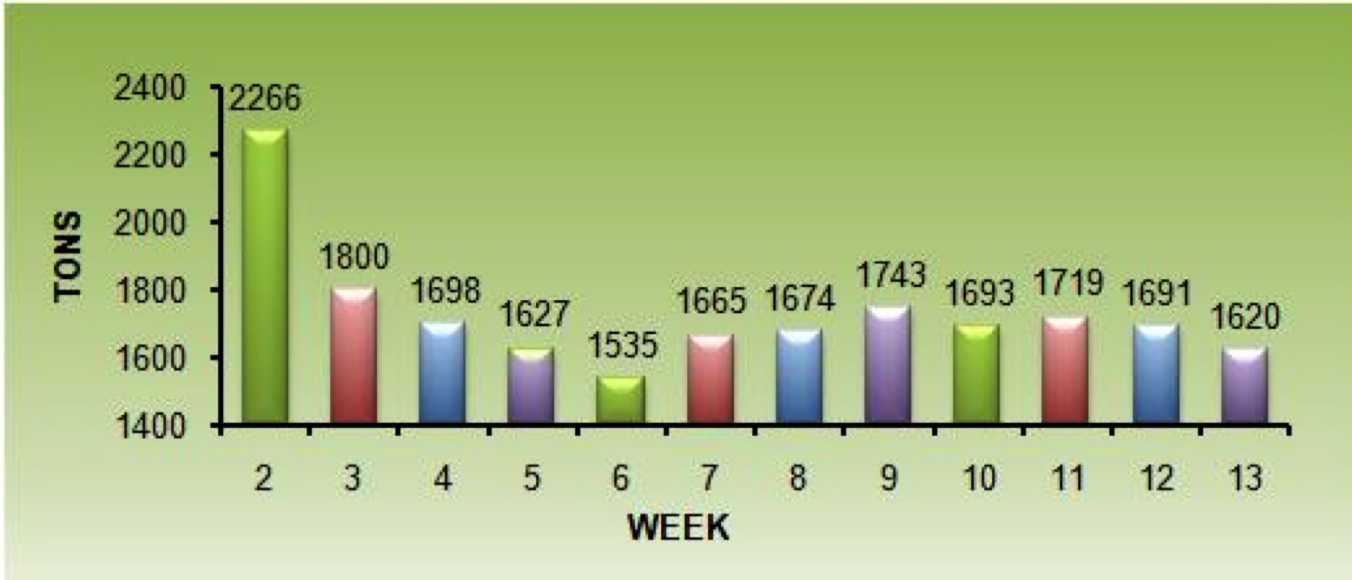

Fig. (2). MSW collected in the first quarter of 2009. 
(SEMARNAT) [35], reports that the beneficial use of waste for recycling is $52.02 \%$ and for energy recovery is $29.44 \%$. One explanation for these differences may be that the recycling culture in the community is increasing; therefore, waste with potential value is not discarded for later collection by the waste collection services. This might be due to the promotion and support of recycling campaigns launched by the municipality and nongovernmental organizations (NGO).

In the international stage, for example, a study carried out in Hong Kong and Dublin shows that the domestic household waste generated separately in these two cities that can be recycled is $51.4 \%$ and $50.5 \%$, respectively [23]. These percentages are higher than the ones found and set forth in this study (approximately 10\%). This may be because within the recyclables reported in those studies are included disposable diapers, while in the research reported here diapers are not considered as recyclable for not having adequate facilities for its recycling.

It is known that the facts and figures about the waste reported in the U.S.-Mexican border have the particular characteristic of less organic content than in the rest of Mexico. Research carried out in several places around Mexico show that, indeed, the organic composition of food scraps and yard trimmings is lower in the north border region. For example, the results published by BernachePérez et al. [26] in Guadalajara show food scraps at $40.7 \%$, yard trimmings at $12.2 \%$, paper at $10 \%$, and plastics at $9 \%$. On the other hand, Buenrostro [25] reports that food scraps in Morelia accounted for $50.95 \%$, paper $7.62 \%$ and plastics $7.68 \%$. As to Chihuahua, Gómez et al. [24] reports that out of the total amount of waste generated, $48.0 \%$ is food scraps, $16.1 \%$ is paper, and $11.9 \%$ plastics.

Different fact and figures regarding waste composition were found in other countries. For example, organic waste generated in Portugal accounts for 27.4\%, paper accounts for $20.3 \%$, plastics $18 \%$, glass $6 \%$, metals $5 \%$, and textiles $3.8 \%$ [36]. In Missouri, USA, the waste composition reported paper at $41 \%$, organics at $21 \%$, plastics at $16 \%$, metals at $6 \%$, glass at $3 \%$, and other waste at $13 \%$ [5]. In Cyprus, waste composition reported paper at $24 \%$, plastics at $5 \%$, food scraps at $39 \%$, yard trimmings at $14 \%$, glass at $1.5 \%$, and metals at $2 \%$ metals [37]. In every study mentioned, the organic waste compositions generated in these countries are lower than the one reported in Mexico. Ensenada's waste composition most closely resembles that of Cyprus. As for the composition of glass and metal, the difference can be partially attributed to the informal recycling.

\section{Daily Per Capita Generation}

In the present study, it was determined that Ensenada's municipal solid waste is $0.87 \pm 0.07 \mathrm{~kg}$ per person per day. Such a figure lies below the 1.3837 -kg-per-person-per-day estimate proposed by the National Institute of Ecology [38] for Ensenada in 2010 (444 grams above the upper limit). SEMARNAT [35] reported that the daily per capita generation in the border zone in 2006 was $1.06 \mathrm{~kg}$ per person per day. The figure found in the present study was lower than the one set forth in the study previously mentioned.
Other studies carried out along the Mexican border show that the waste generation in Reynosa is $1.96 \mathrm{~kg}$ per person per day, in Ciudad Juárez is $1.21 \mathrm{~kg}$ per person per day, and in Tijuana is $1.17 \mathrm{~kg}$ per person per day [39]. All of these figures are above one kilogram per person per day, higher than the per capita generation estimated for Ensenada, which is the most similar to Tijuana's. In contrast to what was found by Ojeda et al. [28], Mexicali's waste generation is $0.592 \mathrm{~kg}$ per person per day, probably due to the data sampling period, which was in two stages: from May to June of 1999 and from March to April of 2000. The findings have shown that Ensenada's waste generation, to date, corresponds to just the first quarter of 2009. Other reasons for this may be 1) the political elections in 2000, where political propaganda materials had an impact on waste generation, and 2) Mexicali's greater recycling culture over that of Ensenada as well as more recycling-oriented enterprises in the city. It is important to state that in these previously mentioned studies, the samplings were done doorto-door, contrary to sampling in this study, where the sampling was done right from the waste collection trucks.

Findings from this study show the opposite of what happens in other cities around the country. Lower figures are shown by Gómez et al. [24] in Chihuahua with $0.676 \mathrm{~kg}$ per person per day, Bernache-Pérez et al. [26] in Guadalajara with $0.580 \mathrm{~kg}$ per person per day, and Buenrostro [25] in Morelia with $0.629 \mathrm{~kg}$ per person per day. Compared to other cities worldwide, it can be observed that daily per capita generation in Ensenada is similar to the generation rates described by Hristovski et al. [40] with $1.06 \pm 0.56 \mathrm{~kg}$ in Veles, Macedonia (developing economy); Bernache-Pérez et al. [26], who states that developed countries such as Japan generates $1.22 \mathrm{~kg}$ per person per day and Germany $1.15 \mathrm{~kg}$ per person per day; and Gomes et al. [36], who states that Portugal generates $1.2 \mathrm{~kg}$ per person per day. This is in contrast to other developed countries such as the United States with a daily per capita generation of $1.98 \mathrm{~kg}$ per person per day and Canada with $1.64 \mathrm{~kg}$, countries where a stressed difference may be noted.

\section{CONCLUSIONS}

Knowledge about household waste composition is essential in order to properly plan its management. To know the organic waste proportions is relevant to estimate the methane gas generation during anaerobic decomposition and reuse the waste to generate energy or to use this portion to produce compost. In this regard, this study shows that Ensenada's waste contains an organic component of above $60 \%$, taking into account paper and cardboard.

The large amount of waste generated in the city $(86.36 \%)$ could be reused, whether by recycling or energy recovery, thereby generating financial, environmental, and social returns that would otherwise be lost to disposal in the sanitary landfill. However, due to a combination of the lack of waste management plans and conservation, recycling practices and recycling industry development policies, as well as recycling licensees' financial interests with the ignorance of local authorities regarding the potential value of waste material, the disposal of potentially marketable waste material is a practice that will likely continue. 


\section{ACKNOWLEDGEMENTS}

This work was funded by CONACYT FOMIX-BC and is part of doctoral research project the first author. We thank the Direction of Ecology and the Direction of Public Services Municipal, belonging to the Secretariat of Urban Management of Municipal Government Ensenada of the XIX City Council Ensenada for the facilities granted to carry out this investigation.

\section{REFERENCES}

[1] O. Buenrostro, and G. Bocco, "Solid waste management in municipalities in Mexico: goals and perspectives", Resour. Conserv. Recycl., vol. 39, pp. 251-263, March 2003.

[2] G.M. Ayininuola. and M.A. Muibi, "An engineering approach to solid waste collection system: Ibadan North as case study", Waste Manage., vol. 28, pp. 1681-1687, February 2008.

[3] P.T. Williams, Waste Treatment and Disposal, John Wiley \& Sons, 1998.

[4] G. Tchobanoglous, H. Theisen, and S. Vigil, Gestión Integral de Residuos Sólidos, Madrid, España: McGraw-Hill, 1994.

[5] Y. Zeng, K.M. Trauth, R.L. Peyton, and S.K. Banerji, "Characterization of solid waste disposed at Columbia Sanitary Landfill in Missouri", Waste Manage. Res., vol. 23, pp. 62-71, January 2005.

[6] E. Gidarakos, G. Havas, and P. Ntzamilis, "Municipal solid waste composition determination supporting the integrated solid waste management system in the island of Crete", Waste Manage., vol. 26, pp. 668-679, April 2006.

[7] N. Chang, and E. Davila, "Municipal solid waste characterizations and management strategies for the Lower Rio Grande Valley, Texas", Waste Manage., vol. 28, pp. 776-794, June 2008.

[8] M. Giugliano, M. Grosso, and L. Rigamonti, "Energy recovery from municipal waste: A case study for a middle-sized Italian district", Waste Manage., vol. 28, pp. 39-50, June 2008.

[9] P. Lawson, "Landfill, Microbiology and Research: An Introduction to the Workshop", Landfill Microbiology: $R \& D$ Workshop, pp. 1-9, 1989.

[10] A. Marshall, "Growing bigger", Waste Management World, vol. 8, 2007.

[11] F. Robles Martínez, Generación de biogás y lixiviados en los rellenos sanitarios, México: Instituto Politécnico Nacional, 2008.

[12] K.L. Shah, Basics of Solid and Hazardous Waste Management Technology, United States of America: Prentice Hall, 2000.

[13] S.L. Machado, M.F. Carvalho, J. Gourc, O.M. Vilar, and J.C.D. Nascimento, "Methane generation in tropical landfills: Simplified methods and field results", Waste Manage., vol. 29, pp. 153-161, January 2009.

[14] EPA - LMOP, Turning a Liability into an Asset: A Landfill Gas-toEnergy Project Development Handbook, United States of America: Environmental Protection Agency, 1996.

[15] EPA - METHANE TO MARKETS, "Landfill Methane Recovery and Use Opportunities", 2008.

[16] S. Kumar, A. Mondal, S. Gaikwad, S. Devotta, and R. Singh, "Qualitative assessment of methane emission inventory from municipal solid waste disposal sites: a case study", Atmos. Environ., vol. 38, pp. 4921-4929, April 2004.

[17] R. Bove, and P. Lunghi, "Electric power generation from landfill gas using traditional and innovative technologies", Energy Conversion Manage., vol. 47, pp. 1391-1401, August 2006.

[18] F.G. Pohland, and S.R. Harper, Critical Review and Summary of Leachate and Gas Production from Landfills, EPA-600/2-86-073. Washington DC: 1986.

[19] L. Lombardi, E. Carnevale, and A. Corti, "Greenhouse effect reduction and energy recovery from waste landfill", Energy, vol. 31, pp. 32083219, May 2006.
[20]

SEMARNAT, Guía para la gestión integral de los residuos sólidos municipales, México: 2001.

[21] S. Ojeda Benítez, "El consumo como fuente de generación de basura y contaminación", Contaminación y medio ambiente en Baja California, México: Universidad Autónoma de Baja California y Miguel Angel Porrúa, librero-editor, pp. 227-249, May 2006.

[22] B.E.J. Jiménez Cisneros, La contaminación ambiental en México, México: Limusa, 2002.

[23] S. Chung and C. Poon, "Characterisation of municipal solid waste and its recyclable contents of Guangzhou", Waste Manage. Res., vol. 19, pp. 473-485, February 2006.

[24] G. Gomez, M. Meneses, L. Ballinas, and F. Castells, "Characterization of urban solid waste in Chihuahua, Mexico", Waste Manage., vol. 28 , pp. 2465-2471, June 2008.

[25] O. Buenrostro Delgado, Los residuos sólidos municipales. Perspectivas desde la investigación multidisciplinaria, México: Universitaria, 2001.

[26] G. Bernache-Perez, S. Sanchez-Colon, A.M. Garmendia, A. DavilaVillarreal, and M.E. Sanchez-Salazar, "Solid waste characterisation study in the Guadalajara Metropolitan Zone, Mexico", Waste Manage. Res., vol. 19, pp. 413-424, July 2001.

[27] G. Gómez, M. Meneses, L. Ballinas, and F. Castells, "Seasonal characterization of municipal solid waste (MSW) in the city of Chihuahua, Mexico", Waste Manage., vol. 29, pp. 2018-2024, September, 2009.

[28] S. Ojeda-Benitez, C. Armijo-de Vega, and M.E. Ramírez-Barreto, "Characterization and quantification of household solid wastes in a Mexican city”, Resour., Conserv. Recycl., vol. 39, 2003, pp. 211-222.

[29] S. Ojeda-Benítez, C. Armijo-de Vega, and M.Y. Marquez-Montenegro, "Household solid waste characterization by family socioeconomic profile as unit of analysis", Resources, Conserv. Recycl., vol. 52, pp. 992-999, January 2008.

[30] SCINCE, "The System for Consultation of Censuses Information", 2000.

[31] NMX-AA-015-1985, Norma Mexicana NMX-AA-015-1985, México: Secretaria de Comercio y Fomento Industrial. Protección al AmbienteContaminación del Suelo-Residuos Sólidos Municipales-MuestreoMétodo de Cuarteo.

[32] NMX-AA-022-1985, Norma Mexicana NMX-AA-022-1985, México Secretaria de Comercio y Fomento Industrial. Protección al AmbienteContaminación del Suelo-Residuos Sólidos Municipales-Selección y cuantificación de Subproductos.

[33] S. Ojeda Benítez, C. Armijo de Vega, and M.E. Ramírez Barreto, "Gestión de residuos sólidos municipales", Una visión de la problemática ambiental de Mexicali y su valle, México: UABC, pp. 137-167, January 2006.

[34] SEDESOL, Proyecto de relleno sanitario y estudio de impacto ambiental en Ensenada, B.C., México: 1998

[35] SEMARNAT, "Compendio de Estadísticas Ambientales 2008”, 2008.

[36] A. Gomes, M. Matos, and I. Carvalho, "Separate collection of the biodegradable fraction of MSW: An economic assessment", Waste Manage., vol. 28, pp. 1711-1719, September, 2008.

[37] P. Eleftheriou, "Energy from waste: a possible alternative energy source for large size municipalities", Waste Manage. Res., vol. 25, pp. 483486, March 2007.

[38] INE, Estadísticas e indicadores de inversión sobre residuos sólidos municipales en los principales centros urbanos de México, México: 1997.

[39] I. Couto Benítez, "Evaluación de la gestión integral de residuos sólidos urbanos en la frontera norte: los casos de Juárez, Reynosa y Tijuana", Tesis de Maestría, El Colegio de la Frontera Norte, 2008.

[40] K. Hristovski, L. Olson, N. Hild, D. Peterson, and S. Burge, "The municipal solid waste system and solid waste characterization at the municipality of Veles, Macedonia", Waste Manage., vol. 27, pp. 16801689, December 2007. 